\title{
The Reform of Blended Courses for Software Project Management
}

\author{
Liping $\mathrm{Li}^{*}$ and $\mathrm{Na}$ Wang \\ Computer and Information Engineering Institute, Shanghai Polytechnic University, Shanghai, China
}

\begin{abstract}
Blended teaching is a teaching method integrating classroom teaching and online learning. Based on OBE (Outcome-based education), this paper proposes some reform ideas for blended teaching by software project management curriculum. Project driven, flipped classroom, vivid animations, MOOC video and cases study etc. are adopted to improve the self-study ability and team work of students. Although it takes more time to study, it gain high praise and enhance the teaching quality.
\end{abstract}

\section{Introduction}

Online teaching has gained more and more attention because of the COVID-19. With the deep integration of Internet and teaching, the design and application of blended teaching has become one of the key contents on the reform of teaching methods in colleges and universities. [1] Software project management is a comprehensive curriculum which stress on both theory and practice. Through this course study, students should grasp the basic theory, method, processes, tools and apply them in software project management practice. [2] As we know, students should study the theories, methods and some popular tools in advance, so they can better apply the learned knowledge on work and make a good basis for an excellent software project manager later.

OBE (Outcome-based education) is a kind of educational philosophy which is "student -centered, achievement oriented and continuous improvement". Focus on "what learners can actually do with what they know and have learned". [3] Based on OBE continuous improvement, we update teaching methods through blended teaching, cultivate students' self-study ability and improve students' interest in learning, in order to realize the teaching goal of " knowledge, thinking and apply".

Based on the previous achievements on software project management curriculum, this paper introduces some reform methods for blended teaching. Teaching means has changed from "teacher-centered" to "student-centered". The teaching process mainly adopts "project driven -> flipped classroom -> method inspiration -> animation demonstration -> cases study -> quiz" to improve students' participation, promote their independent thinking and

* Corresponding author: liliping@sspu.edu.cn 
self-study ability. The purpose is make students better understand the learned knowledge and use them to solve the actual project management problems.

\section{The Relationship for Graduation Requirements and Curriculum Objectives}

Software project management is an important course that can transform students' early knowledge into ability and improve students' career development. Software project management consists of a number of activities, which includes planning of project, deciding scope of software product, estimation of cost in various terms, scheduling of tasks and events, and resource management. [3] This course is set up for Senior Software Engineering Undergraduates in our school, which is a required professional course. At present, 32 class hours are allocated. The number of students is 2-3 classes per year, about $90-140$. Since this course was opened in 2009, there are 13 software engineering sessions have taken this course.

Table 1. The supporting relationship

\begin{tabular}{|c|c|c|}
\hline $\begin{array}{c}\text { Graduation } \\
\text { Requirements }\end{array}$ & Graduation Requirements Index & $\begin{array}{c}\text { Supporting } \\
\text { Relationship }\end{array}$ \\
\hline $\begin{array}{c}\text { 3. Design / } \\
\text { Development } \\
\text { solutions }\end{array}$ & $\begin{array}{c}\text { 3.4: be able to consider social, health, safety, legal, } \\
\text { cultural and environmental factors in software design }\end{array}$ & $\begin{array}{c}\text { Curriculum } \\
\text { Objective 3 }\end{array}$ \\
\hline $\begin{array}{c}\text { 9. Individuals } \\
\text { and Teams }\end{array}$ & $\begin{array}{c}\text { 9.2: be able to take corresponding responsibilities in the } \\
\text { role of individual, team member and leader in the team, } \\
\text { and cooperate well with others. }\end{array}$ & $\begin{array}{c}\text { Curriculum } \\
\text { Objective 2 }\end{array}$ \\
\hline $\begin{array}{c}\text { 10. } \\
\text { Communication }\end{array}$ & $\begin{array}{c}\text { 10.2: have good communication skills, be able to clearly } \\
\text { express opinions and make statements on complex } \\
\text { software engineering problems, and effectively } \\
\text { communicate with peers in the industry and the public }\end{array}$ & $\begin{array}{c}\text { Curriculum } \\
\text { Objective 2 }\end{array}$ \\
\hline $\begin{array}{c}\text { 11. Project } \\
\text { Management }\end{array}$ & $\begin{array}{c}\text { 11.1: understand the characteristics of software project } \\
\text { development, master the concept and method of project } \\
\text { management. }\end{array}$ & $\begin{array}{c}\text { Curriculum } \\
\text { Objective 1 }\end{array}$ \\
\hline $\begin{array}{c}\text { 11. Project } \\
\text { Management }\end{array}$ & $\begin{array}{c}11.2: \text { be able to make economic feasibility analysis and } \\
\text { decision on software projects }\end{array}$ & $\begin{array}{c}\text { Curriculum } \\
\text { Objective 3 }\end{array}$ \\
\hline $\begin{array}{c}\text { 11. Project } \\
\text { Management }\end{array}$ & $\begin{array}{c}11.3: \text { have the ability to apply engineering management } \\
\text { principles and economic decision-making methods to } \\
\text { manage complex software engineering projects in a } \\
\text { multidisciplinary environment. }\end{array}$ & $\begin{array}{c}\text { Curriculum } \\
\text { Objective 1 }\end{array}$ \\
\hline
\end{tabular}

The basic idea of OBE is "student-centered", focus on students' learning achievements, emphasize what abilities students have by learning, what graduation requirements they should meet. There are 12 graduation requirements and students should achieve the goal after 5 years graduate. [3] We should make clear the curriculum objectives and which of the 12 graduation requirements the course supports. There are three curriculum objectives for software project management, shown as follows:

Curriculum objective 1 . Students are required to master the characteristics of software project management, the basic concepts, principles and methods of 10 knowledge areas and 5 process groups of project management, and can manage software projects with engineering ideas, and enhance the ability of analysing and solving complex software engineering problems. 
Curriculum objective 2. Students should grasp the basic technology and common tools in each stage of software project management, to ensure the successful implementation of the project. Should master how to write important technical documents. And understand the role and relationship of individuals, team members and leaders in complex software engineering practice under the multi-disciplinary background.

Curriculum Objective 3. Students should know how to conduct economic feasibility analysis and decision-making on software engineering projects, analyze and evaluate objectively the impact of software engineering practice and complex software engineering problem solutions on society, health, safety, law and culture.

The supporting relationship between graduation requirements and curriculum objectives is shown as table 1. [4]

\section{Reform of Blended Teaching Method}

\subsection{Classroom Teaching}

To learn software project management curriculum better is to know some management rules, study some good cases, consult a series of standard templates and master some popular tools for project management. [5]

Software project management curriculum on our school was approved as the key curriculum of Shanghai on 2017, and the excellent curriculum of our university on 2019. A variety of teaching methods and means are used in the teaching. We have acculmulated rich and diverse curriculum resources. MOOC video have been recorded by ourseleves. After the use in the spring semester, the students reflected that the video content is comprehensive and explain clearly, which has made a very good foundation for the online and offline blended teaching. With the continuous improvement, this curriculum is deeply loved by students. The details of the classroom teaching reform are mainly shown as follows:

First, we do many investigations and academic exchanges with enterprises and other colleges and universities. We must know newest technologies, methods and the needs of enterprises, and then integrate them into teaching. Meanwhile, the syllabus, teaching content, teaching methods and teaching means of the course are updated to ensure the timeliness to a certain extent.

Second, we have collected some classic cases and established a teaching case library. There are four complete cases which covering the whole processes of software project management, including object-oriented method and traditional structured method. Cases study teaching improves the teaching effect.

Third, professional MOOCS videos have been recorded and put on the course website for students to learn. Because the COVID-19 epidemic, online teaching was implemented in our school, the video was used and the students' evaluation was very good.

Fourth, we have written the experimental instruction. Software project management course is very practical, in order to master the actual process of software project management and grasp the theoretical knowledge, it also needs a lot of practical experience. In practice teaching, we stress on the teaching of integrating theory with practice. Simulating the real software develop environment, conduct the whole process of project management, more cases analysis and organize more discussions. Project practice can improve students' analytical ability and practical ability.

Fifth, the vivid course animation simulating the actual scene of software project management. These animations let students understand the actual operation of software 
project management better. Make more boring theoretical knowledge easier to remember and understand. Enhance students' interest in learning and achieved excellent results.

Sixth, the complete set of exercises has been compiled, including after class exercises and answers, PMP examination exercises and various exercises; the types of questions include single choice questions, fill in the blanks, short answer questions and case analysis questions. Homework and practice are very important to consolidate the learned knowledge. So, appropriate homework and practice work should be assigned to students. And they are important part of assessment.

\subsection{Blended Teaching Reform}

Teaching methods and means will be "student-centered", using "project driven and case study", online and offline blended teaching method. Online course resources are very rich. We have built a course website with complete learning resources based on ChaoXing platform, including: MOOC video by ourselves, course plan, syllabus, schedule, case library, exercise library, experiment guide, scene animation, catchy formula and document template and online communication etc. Through the website, students can obtain learning materials all day, communicate with each other, and submit assignments, which greatly facilitates students' learning. It is convenient to cultivating the students' autonomous learning ability.

Based on the concept of flipped classroom, the blended teaching process is shown as figure 1. [6]

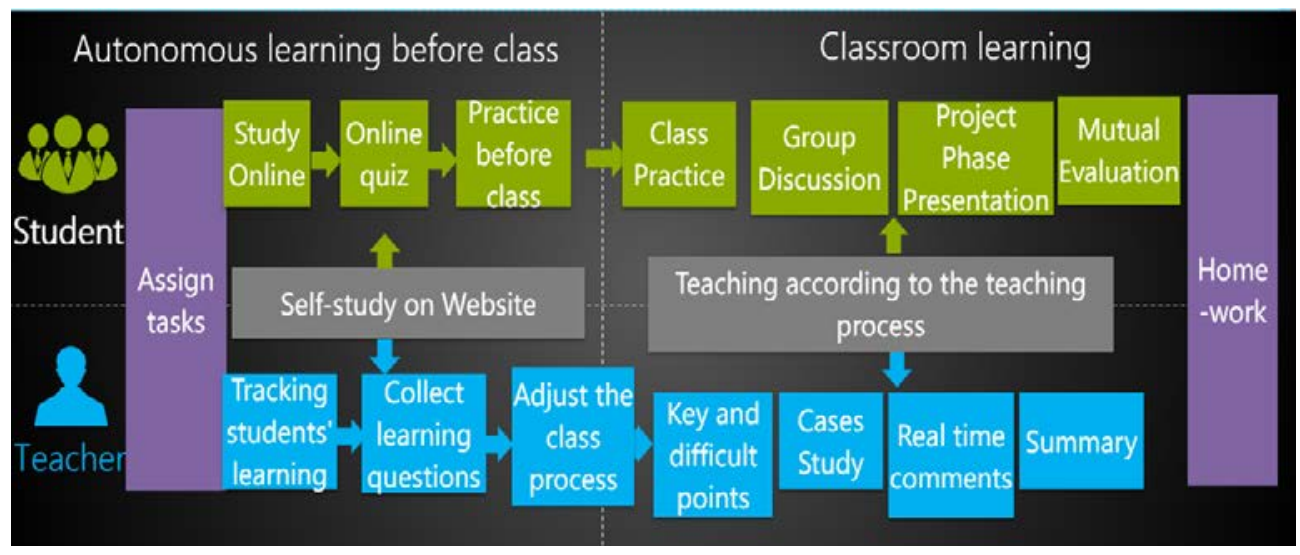

Fig. 1. The Blended Teaching Process

1) Before class, students should familiar with the blended teaching process, and know clearly about the learning objectives, learning requirements and the contents to be prepared before class.

2) Online learning, watching recorded MOOC videos, teaching materials and online learning materials. The video content is rich, the explanation is detailed, and some animation and exercises are interspersed, which improves the interest and practicability of the course video, and facilitates students' preview before class and review after class.

3) Teachers should track students' learning situation, collect online learning problems, and adjust the class process accordingly.

4) The key and difficult points of knowledge are mainly explained in class, and the learned knowledge is tested through questions and classroom exercises. Through "case analysis -> group discussion -> stage report ->mutual comments -> induction and summary", consolidate the knowledge points learned and improve the ability of knowledge 
transformation. Teaching activities should be fully designed in class to arouse students' learning enthusiasm and change the traditional "teacher-centered" to "student-centered" learning.

\subsection{Assessment Reform}

Process assessment is a very important part for this course reform. Online and offline learning process and results need to be evaluated. In order to ensure the effect of pre-class learning, Teachers should track and evaluate students' learning situation, collect online learning problems and ask questions in class. The details are as follows:

1) Online learning assessment $40 \%$, include two parts: online learning participation $20 \%$ and examination score $20 \%$. The main assessment of online course participation, including statistics of the number of video viewers, the proportion of average video viewing time, the number and quality of students' questions. Examination score is mainly about the completion of online quiz and online course assignments.

2) Classroom learning and final assessment: 60\%. It mainly includes students' usual classroom performance, group discussion and final project work, etc. Assessment is very important to this project-driven teaching mode. The final examination is changed from the traditional paper examination to the project work. Divide 3-5 students into a team, select a project, and use the method of software project management to analyse, plan and manage the project. At each phase, we choose 1-2 teams to present their work of on class, other students listen, ask questions and discuss for their presentation. At the end of class, the teacher review and summary for the presentation. After the presentation, students can revise their project work according to the comments and suggestion. Each team have 2 opportunities to modify and rework. Such a repeated process is very helpful for students to master the theoretical knowledge of software project management. At last, each team should submit all their work including the project plan, source code, documents and prepare for a presentation. The final score for project work is also given in proportion.

3) Students are instructed to attend professional qualification certificate like "ruankao" etc. The professional certificate can strengthen student's professional direction, consolidate and check the learning knowledge. Professional certificate also can do help for students to find jobs. If students get some professional qualification certificate about project management, he can apply for exemption.

With the blended teaching and project practice, students could learn this curriculum better. Most students giving positive feedback. Due to space limitation, we give some feedback of students, shown as Figure 2.

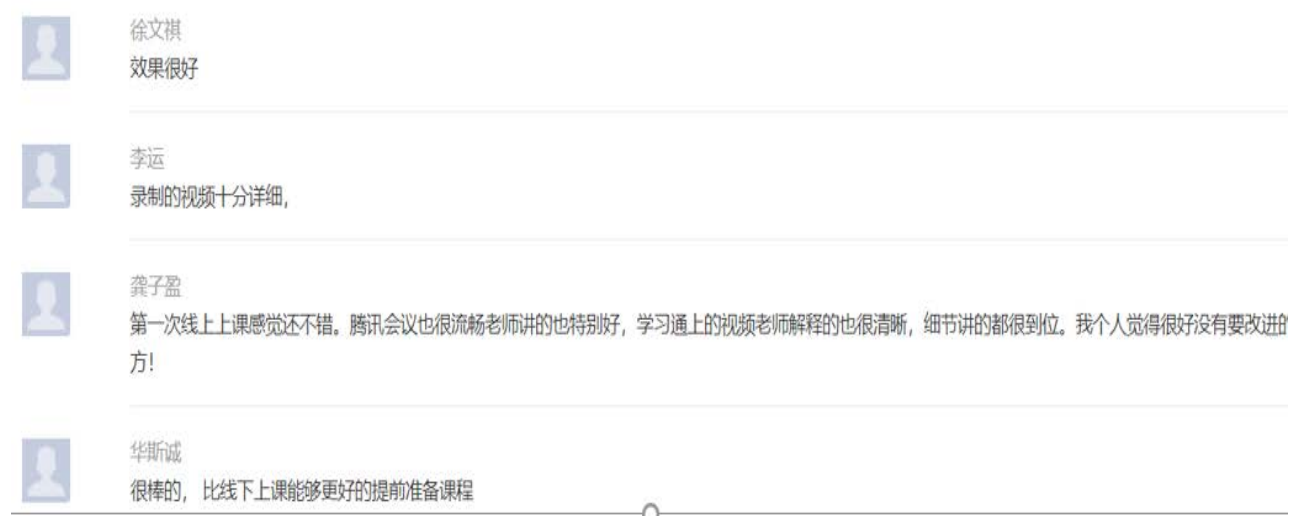

Fig. 2. Good feedback from students 


\section{Summary}

Nowadays, the ability of project management gets more and more attention. As one of the core curriculum for software engineering and related majors, this paper proposes some reform ideas for blended teaching on software project management curriculum. The syllabus, teaching content, teaching mode and teaching methods based on OBE have been enriched and completed. The online and offline blended teaching mode and teaching methods suitable for cultivating application-oriented talents are explored. Although blended teaching increases the study time and pressure, it improves the quality of teaching and most students like the new teaching mode. We hope these reform ideas will do some help to your teaching improvement.

\section{References}

1. LYUWan-qin, GEXu-feng. An empirical research on college students' acceptance of blended learning -integrated model based on TAM and TPB, Journal of Yunnan University 2020, 42(S1):97 105.

2. A Guide to the Project Management Body of Knowledge (Seventh Edition) (PMBOK Guide) [M], Project Management Institute, 2020.

3. Outcomes Based Education: https://www.researchgate.net/publication/317209834_Outcomes_Based_Education

4. Liping Li, Na Wang, Shan Tang. OBE-BasedReform for Software Project Management Curriculum", 2019 14th International Conference on Computer Science \& Education (ICCSE), August 19-21, 2019. Toronto, Canada, pp 1075-1079.

5. Software Project Management. https://www.tutorialspoint.com/software_engineering/software_project_management.h tm.

6. PPT courseware for online and offline mixed teaching https://wenku.baidu.com/view/5bda91b1b42acfc789eb172ded630b1c59ee9b9e.html?fi xfr=S2Z91TV0gEqiYakCm5xeRQ\%253D\%253D\&fr=income6-wk_sea_vipX-search 